\title{
OCCURRENCE OF ANURANS IN BRAZILIAN CAVES
}

\section{POJAVLJANJE BREZREPIH DVOŽIVK V BRAZILSKIH JAMAH}

\author{
Rodrigo MATAVELLI ${ }^{1 *}$, Aldenise MARTINS CAMPOS ${ }^{2}$, Renato NEVES FEIO ${ }^{3}$ \\ \& Rodrigo LOPES FERREIRA ${ }^{4}$
}

\begin{abstract}
UDC 597.9:551.442(81)

Rodrigo Matavelli, Aldenise Martins Campos, Renato Neves Feio \& Rodrigo Lopes Ferreira: Occurrence of anurans in brazilian caves

Brazil has the greatest diversity of anurans and also one of the greatest speleological patrimonies in the world. However, informations about anurans in Brazilian caves including different biomes and lithologies are scarce. This study sampled 223 caves divided into different biomes (Amazon, Atlantic Forest, Caatinga, Cerrado and transition areas) and lithologies (Conglomerate, Granite, Iron-ore, Limestone, Marble, Quartzite, and Sandstone) distributed in eleven Brazilian states. To determine the anuran composition (presence/absence), a single sampling event was conducted in each cave by a team of three researchers in the period 1999-2011, following acoustic and visual search methods. We recorded 54 species distributed in 18 genera and 11 families. The caves in the Amazon biome had the highest number of species, followed by caves present in the Cerrado, Caatinga, transition areas (Atlantic Forest and Cerrado) and the Atlantic Forest. The caves in the Iron-ore lithology had the highest number of species, followed by the Limestone, Sandstone, Quartzite, Granite, Marble and Conglomerate caves. The anurans proved to be very diverse in Brazilian caves, with this high species richness related to the large amount of biomes and lithologies sampled. The family Leiuperidae had the highest richness and the species Scinax fuscovarius the highest frequency of occurrence in the caves. Also recorded were tadpoles and immature forms inside caves suggesting that not all the species are accidental, and that some species may be using these environments for shelter, protection, food and, even reproduction.
\end{abstract}

Keywords: Anura, biome, Brazil, conservation, lithology, Neotropical.

Izvleček

UDK 597.9:551.442(81)

Rodrigo Matavelli, Aldenise Martins Campos, Renato Neves Feio \& Rodrigo Lopes Ferreira: Pojavljanje brezrepih dvoživk $v$ brazilskih jamah

Brazilija ima največjo raznolikost brezrepih dvoživk (brezrepcev) na svetu in izjemno speleološko dediščino. Podatkov o razširjenosti brezrepcev $\mathrm{v}$ Brazilskih jamah je malo. V članku poročamo o vzorčevanju v 223 jamah $\mathrm{v}$ različnih biomih (Amazonija, atlantski gozd, cerrado (brazilska savana), caatinga in vmesna (prehodna) območja) in na različnih litoloških podlagah (konglomerat, granit, železova ruda, apnenec, marmor, kvarcit in peščenjak) $v$ enajstih zveznih državah. $V$ vsaki od jam je bilo narejeno eno vzorčenje med leti 1999 in 2011 . Vzorčili smo vizualno in akustično ter našli 54 vrst, 18 rodov in 11 družin brezrepcev. Največ vrst smo našli v jamah amazonskega bioma, ki mu sledijo jame v cerradu, caatingi, mešanem območju (atlantski gozd in cerrado) in $\mathrm{v}$ atlantskem gozdu. $\mathrm{Z}$ vidika litološke podlage, smo največjo vrstno raznolikost brezrepcev našli $\mathrm{v}$ jamah $\mathrm{v}$ železovi rudi, ki jim sledijo jame v apnencu, peščenjaku, kvarcitu, granitu, marmorju in konglomeratu. Raznovrstnost brezrepcev v brazilskih jamah je zaradi raznolikih biomov in litologij velika. Najbolj bogato zastopana je družina Leiuperidae, med vrstami pa je najbolj pogosta Scinax fuscovarius. Našli smo tudi paglavce in druge nezrele oblike, kar kaže, da bi lahko nekatere vrste jamsko okolje uporabljale za zavetje, zaščito, hrano ali celo razmnoževanje.

Ključne besede: brezrepe dvoživke, biom, zaščita, litologija, neotropik, Brazilija.

${ }^{1}$ Universidade Federal de Lavras, Departamento de Biologia, Setor de Ecologia Aplicada. Campus da UFLA s/n ${ }^{\circ}$, CEP: 37.200-000, Lavras, MG, Brasil

${ }^{2}$ Universidade Federal de Minas Gerais, Programa de Pós-Graduação em Ecologia, Conservação e Manejo da Vida Silvestre. Avenida Antônio Carlos, N 6627, Pampulha, CEP: 31270-901, Belo Horizonte, MG, Brasil

${ }^{3}$ Universidade Federal de Viçosa, Departamento de Biologia Animal. Campus da UFV s/nº, CEP: 36.571-000, Viçosa, MG, Brasil

${ }^{4}$ Centro de Estudos em Biologia Subterrânea, Departamento de Biologia, Setor de Zoologia, Universidade Federal de Lavras,

Campus da UFLA s/nº, CEP: 37.200-000, Lavras, MG, Brasil

* Corresponding author: e-mail: ram_eco@yahoo.com.br

Received/Prejeto: 10.10 .2013 


\section{INTRODUCTION}

Brazil has the greatest diversity of anurans in the world with 1.026 species (Segalla 2014) and also one of the most valuable and diverse speleological patrimonies in the world due to their extent, grandeur, beauty and scientific importance (Auler et al. 2001). However, the cave fauna in Brazil began to be studied mainly from the 80 's, the earliest works only being conducted with organisms specialized for the specific conditions of these environments (Godoy 1986; Trajano \& Moreira 1991). In the 1990s, there was an upswing of the biospeleological studies in Brazil, which now has the richest cave fauna in South America (Pinto-da-Rocha 1995; Zeppelini-Filho et al. 2003).

Currently, studies about cave biology encompass not only the specialized groups, but the set of all the inter-relationships among the biota, the cave environment and epigean species, i.e., those that inhabit the cave entrances, such as mammals, reptiles and anurans (Trajano 1987; Pinto-da-Rocha 1995; Culver et al. 2004; Trajano \& Bichuette 2006; Köhler et al. 2010; Canedo et al. 2012).

The cave animals are variable with respect to morphology, physiology, and specialization and can be classified into three categories (Holsinger \& Culver 1988 modified from the system of Shinner-Racovitza): Trogloxenes, Troglophiles and Troglobite. (i) the trogloxenes are those who regularly need to leave the caves to complete part of their vital activities in the external environment, often being mainly responsible for the energy flow in permanently dry caves; (ii) the troglophiles are facultative inhabitants of the subterranean environment and complete their life cycle inside or outside the caves and (iii) the troglobites are the animals that are restricted to cave environments. The accidentals are animals from the epigean, "outside", environment, that enter the caves accidentally or even seek these natural cavities for protection, shelter and food, among other situations (Trajano \& Bichuette 2006; Gouveia et al. 2009; Fellers et al. 2010).

Since the 1950's many registrations of anurans in caves have been cited throughout the world including Brazil (Barr 1953; Lee 1969; Trajano 1987; Trajano \& Gnaspini-Neto 1991; Pinto-da-Rocha 1995; Trajano \& Bichuette 2006; Del Castillo et al. 2009; Köhler et al. 2010; Canedo et al. 2012). According Prather and Briggler (2001), some species of anurans even spend part of their life cycle in these environments. Additionally, some tropical species are adapted to hypogean cave environments while others are adapted to life in the edges or ecotones of these environments. However, to date, the anurans found in most studies in Brazilian subterranean environments have been interpreted as accidental (Trajano 1987; Trajano \& Gnaspini-Netto 1991; Pintoda-Rocha 1995). Consequently, previous studies simply reported the presence of anurans without trying to determine the relationship and/or persistence of populations in cave environments.

From this perspective, the objective of this study is to document the occurrence of anurans in natural caves in Brazil encompassing different biomes and lithologies.

\section{MATERIAL AND METHODS}

\section{STUDY AREA}

The study was conducted in 223 caves distributed in 11 Brazilian states such as Pará ( $\mathrm{N}=152$ or $68.16 \%)$, Minas Gerais ( $\mathrm{N}=31$ or $13.90 \%)$, Bahia ( $\mathrm{N}=14$ or $6.28 \%)$, Mato Grosso (N=7 or $3.14 \%)$, Sergipe (N=5 or $2.24 \%)$, Ceará $(\mathrm{N}=4$ or $1.79 \%)$, Espírito Santo ( $\mathrm{N}=4$ or $1.79 \%)$, Río Grande do Norte ( $\mathrm{N}=2$ or $0.90 \%)$, Tocantins $(\mathrm{N}=2$ or $0.90 \%$ ), Río de Janeiro ( $\mathrm{N}=1$ or $0.45 \%$ ) and São Paulo $(\mathrm{N}=1$ or $0.45 \%)$ (Fig. 1).

The sampled caves occur in the Amazon ( $\mathrm{N}=154$ or $69.07 \%$ ), Cerrado ( $\mathrm{N}=24$ or $10.76 \%$ ), Caatinga ( $\mathrm{N}=16$ or $7.17 \%$ ) and Atlantic Forest ( $\mathrm{N}=13$ or $5.83 \%$ ) biomes, which are considered the most threatened of Brazil (Myers 2000; Alencar et al. 2004; Leal et al. 2005; Klink \& Machado 2005) and in transition areas between the At- lantic Forest and Cerrado ( $\mathrm{N}=16$ or $7.17 \%)$. Different lithologies were also included, such as Iron-ore $(\mathrm{N}=163$ or $73.09 \%$ ), Limestone ( $\mathrm{N}=37$ or $16.60 \%)$, Sandstone $(\mathrm{N}=7$ or $3.14 \%)$, Granite ( $\mathrm{N}=6$ or $2.69 \%)$, Quartzite $(\mathrm{N}=6$ or $2.69 \%)$ Conglomerate $(\mathrm{N}=3$ or $1.34 \%)$, Marble ( $\mathrm{N}=1$ or $0.45 \%)$.

\section{SAMPLING OF ANUROFAUNA}

To determine the anuran species composition in the 223 caves, a single sampling event was conducted in each cave by a team of three researchers in the period 1999-2011.

Sampling the anurans was qualitative (presence/ absence) and followed both visual (young/adult) and acoustic search (males in activity vocalization) methods to maximize the number of species observed per 


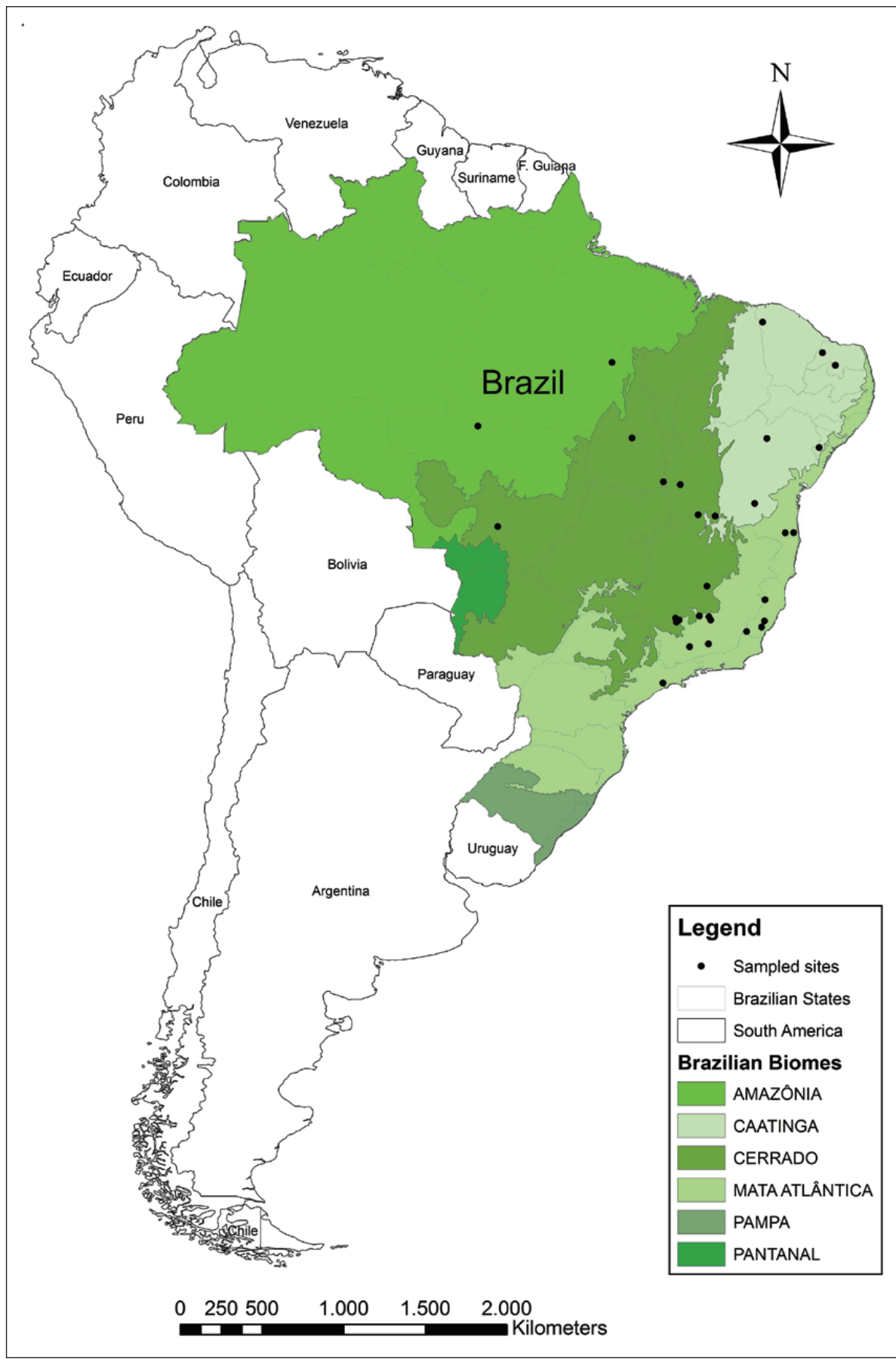

Fig. 1: Map of the study area covering 11 Brazilian states.

cave sampled (Heyer et al. 1994) The entire length of the studied caves was walked and inspected, with special attention to microhabitats with potential for species occurrence, such as cracks in walls and ceilings, beneath rock falls, amid sediment banks and accumulation of organic matter, temporary and permanent ponds and watercourses, when present.

Anurans found in cave environments were captured, identified in situ and released at the same capture location to try to minimize the impact of the collection, considering that these subterranean environments are characterized as some of the most fragile in the world (Elliott 2000; Krajick 2001; Wynne \& Pleytez 2005). Unidentified species were photographed in situ and subsequently identified in the Vertebrate Zoology Laboratory of the Universidade Federal de Viçosa (UFV) with aid of the third author and others taxonomists. 


\section{RESULTS}

We recorded 54 species distributed in 18 genera represented by families Aromobatidae $(\mathrm{N}=3)$, Brachycephalidae $(\mathrm{N}=7)$, Bufonidae $(\mathrm{N}=9)$, Cycloramphidae $(\mathrm{N}=3)$, Dendrobatidae $(\mathrm{N}=2)$, Hylidae $(\mathrm{N}=7)$ Hylodidae $(\mathrm{N}=1)$ Leiuperidae $(\mathrm{N}=10)$ Leptodactylidae $(\mathrm{N}=9)$ Pipidae $(\mathrm{N}=1)$ and $(\mathrm{N}=2)$ for Strabomantidae (Fig. 2, Fig. 3, Tab. 1).

The family, Leiuperidae, had the highest occurrence of species ( $\mathrm{N}=10$ or $18.52 \%)$, followed by the families Bufonidae ( $\mathrm{N}=9$ or $16.68 \%$ ), Leptodactylidae ( $\mathrm{N}=9$ or $16.68 \%$ ), Brachycephalidae ( $\mathrm{N}=7$ or $12.96 \%)$, Hylidae ( $\mathrm{N}=7$ or $12.96 \%)$ Aromobatidae (N=3 or $5.55 \%)$, Cycloramphidae $(\mathrm{N}=3$ or $5.55 \%)$, Dendrobatidae $(\mathrm{N}=2$ or $3.7 \%)$, Strabomantidae ( $\mathrm{N}=2$ or $3.7 \%)$, Hylodidae $(\mathrm{N}=1$ or $1.85 \%)$ and Pipidae ( $\mathrm{N}=1$ or $1.85 \%)$.

Scinax fuscovarius (A. Lutz, 1925) was the species with the highest occurrence in cave environments, present in $(\mathrm{N}=14$ or $6.28 \%)$ of the sampled caves, followed by the species Ischnocnema juipoca ( $\mathrm{N}=6$ or $2.69 \%)$ and Physalaemus gr. cuvieri ( $\mathrm{N}=4$ or $1.79 \%)$.

In the caves inserted in the Amazon biome, 16 species in nine families with 15 unique species for this biome were found. In caves in the Cerrado biome there were 11 species, five families and nine unique species. In caves in the Caatinga biome, we found 11 species, four families and seven unique species. In caves in the Atlantic Forest biome, nine species and six families, all exclusive, were encountered. In caves in the transition areas (Atlantic Forest and Cerrado), 11 species and four families with 10 unique species were observed (Tab. 1).

Among the studied lithologies we recorded 23 species in ten families with 19 exclusive species in Iron-ore formations; Limestone formations, 18 species, five families and 16 exclusive species; Sandstone formations presented seven species, five families and five exclusives; in Quartzite formations we found six species, four families and four unique species; Granite formations yielded four species, three families and three exclusives; Conglomerate formations presented three species, three families and two exclusives and in the Marble cave a single species was found, not exclusive to this lithology (Tab. 1).

Among the 223 cave environments studied, only three caves showed signs of reproductive behaviors such as the presence of tadpoles and juveniles belonging to families Bufonidae (Rhinella sp.) and Hylidae (Dendropsophus aff. nanus).

Tab. 1: Occurrence of anurans in Brazilian caves of different biomes and lithologies. Numbers 1-7 correspond to the different lithologies: 1) Sandstone; 2) Limestone; 3) Conglomerate; 4) Granite; 5) Quartzite; 6) Marble and 7) Iron-ore. Letters A-E correspond to the different biomes: A) Amazon Forest; B) Atlantic Forest; C) Caatinga; D) Cerrado and E) Transition areas "Atlantic Forest and Cerrado".

\begin{tabular}{|c|c|c|c|c|}
\hline Families & Species & Habitats & Biomes & Lithologies \\
\hline \multirow[t]{3}{*}{ Aromobatidae } & Allobates gr. marchesianus (Melin, 1941) & Terrestrial & A & 7 \\
\hline & Allobates sp. & Terrestrial & A & 7 \\
\hline & Allobates sp.1 & Terrestrial & A & 7 \\
\hline \multirow[t]{7}{*}{ Brachycephalidae } & Ischnocnema juipoca (Sazima \& Cardoso, 1978) & Terrestrial & $E$ & $2-3-5$ and 7 \\
\hline & Ischnocnema sp. & Terrestrial & $\mathrm{D}$ & 1 \\
\hline & Ischnocnema sp.1 & Terrestrial & $\mathrm{D}$ & 2 \\
\hline & Ischnocnema sp.2 & Terrestrial & B & 4 \\
\hline & Ischnocnema sp.3 & Terrestrial & $\mathrm{E}$ & 5 \\
\hline & Ischnocnema sp.4 & Terrestrial & E & 5 \\
\hline & Ischnocnema sp.5 & Terrestrial & $E$ & 7 \\
\hline \multirow[t]{9}{*}{ Bufonidae } & Rhaebo guttatus (Schneider, 1799) & Terrestrial & A & 1 and 7 \\
\hline & Rhinella crucifer (Wied-Neuwied, 1821) & Terrestrial & $\mathrm{B}$ & 4 \\
\hline & Rhinella granulosa (Spix, 1824) & Terrestrial & $\mathrm{C}$ & 2 \\
\hline & Rhinella marina (Linnaeus, 1758) & Terrestrial & $\mathrm{D}$ & 7 \\
\hline & Rhinella aff. magnussoni & Terrestrial & A & 7 \\
\hline & Rhinella rubescens (A. Lutz, 1925) & Terrestrial & $E$ & 5 \\
\hline & Rhinella schneideri (Werner, 1894) & Terrestrial & $\mathrm{D}$ & 1 \\
\hline & Rhinella sp. (juvenile) & Terrestrial & B & 2 \\
\hline & Rhinella sp.1 & Terrestrial & B & 2 \\
\hline
\end{tabular}




\begin{tabular}{|c|c|c|c|c|}
\hline Families & Species & Habitats & Biomes & Lithologies \\
\hline \multirow[t]{3}{*}{ Cycloramphidae } & Proceratophrys boiei (Wied-Neuwied, 1825) & Terrestrial & B & 4 \\
\hline & Proceratophrys sp. & Terrestrial & A & 7 \\
\hline & Thoropa taophora (Miranda-Ribeiro, 1923) & Terrestrial & B & 4-5 and 6 \\
\hline \multirow[t]{2}{*}{ Dendrobatidae } & Ameerega flavopicta (A. Lutz, 1925) & Terrestrial & A & 1 and 7 \\
\hline & Adelphobates galactonotus (Steindachner, 1864) & Terrestrial & A & 7 \\
\hline \multirow[t]{7}{*}{ Hylidae } & Bokermannohyla martinsi (Bokermann, 1964) & Arboreal & $\mathrm{E}$ & 7 \\
\hline & Bokermannohyla sp. & Arboreal & $E$ & 7 \\
\hline & Bokermannohyla sp.1 & Arboreal & $\mathrm{E}$ & 7 \\
\hline & Hypsiboas aff. boans & Arboreal & A & 7 \\
\hline & Phyllomedusa burmeisteri Boulenger, 1882 & Arboreal & B & 2 \\
\hline & Scinax fuscovarius (A. Lutz, 1925) & Arboreal & C and $\mathrm{E}$ & 2 and 7 \\
\hline & Dendropsophus aff. nanus (juvenile) & Arboreal & $\mathrm{D}$ & 1 \\
\hline Hylodidae & Hylodes sp. & Terrestrial & B & 3 \\
\hline \multirow[t]{10}{*}{ Leiuperidae } & Physalaemus cuvieri Fitzinger, 1826 & Terrestrial & C and D & 2 \\
\hline & Physalaemus gr. cuvieri & Terrestrial & $\mathrm{C}$ & 2 \\
\hline & Physalaemus aff. ephippifer & Terrestrial & A & 7 \\
\hline & Physalaemus sp. & Terrestrial & $\mathrm{D}$ & 1 \\
\hline & Physalaemus sp.1 & Terrestrial & $\mathrm{D}$ & 1 \\
\hline & Physalaemus sp.2 & Terrestrial & C & 2 \\
\hline & Physalaemus sp.3 & Terrestrial & $\mathrm{E}$ & 7 \\
\hline & Physalaemus sp.4 & Terrestrial & $E$ & 5 \\
\hline & Physalaemus sp.5 & Terrestrial & B & 3 \\
\hline & Physalaemus sp.6 & Terrestrial & C & 2 \\
\hline
\end{tabular}

Leptodactylidae

Leptodactylus labyrinthicus (Spix, 1824)

Leptodactylus mystacinus (Burmeister, 1861)

Leptodactylus macrosternum Miranda-Ribeiro, 1926

Leptodactylus syphax Bokermann, 1969

Leptodactylus troglodytes A. Lutz, 1926

Leptodactylus sp.

Leptodactylus sp. 1

Leptodactylus sp.2

Leptodactylus sp.3

Pipidae

Pipa carvalhoi (Miranda-Ribeiro, 1937)

Strabomantidae
Terrestrial/Aquatic

Terrestrial/Aquatic

Terrestrial/Aquatic

Terrestrial/Aquatic

Terrestrial/Aquatic

Terrestrial/Aquatic

Terrestrial/Aquatic

Terrestrial

Terrestrial

Terrestrial/Aquatic

Terrestrial

Terrestrial

$\begin{array}{cc}\text { D } & 2 \\ \text { D } & 2 \\ \text { C and D } & 2 \\ \text { C and A } & 2 \\ \text { C } & 2 \\ \text { C } & 2 \\ \text { C } & 2 \\ \text { A } & 7 \\ \text { A } & 7\end{array}$

A

7

A $\quad 7$

A $\quad 7$ 

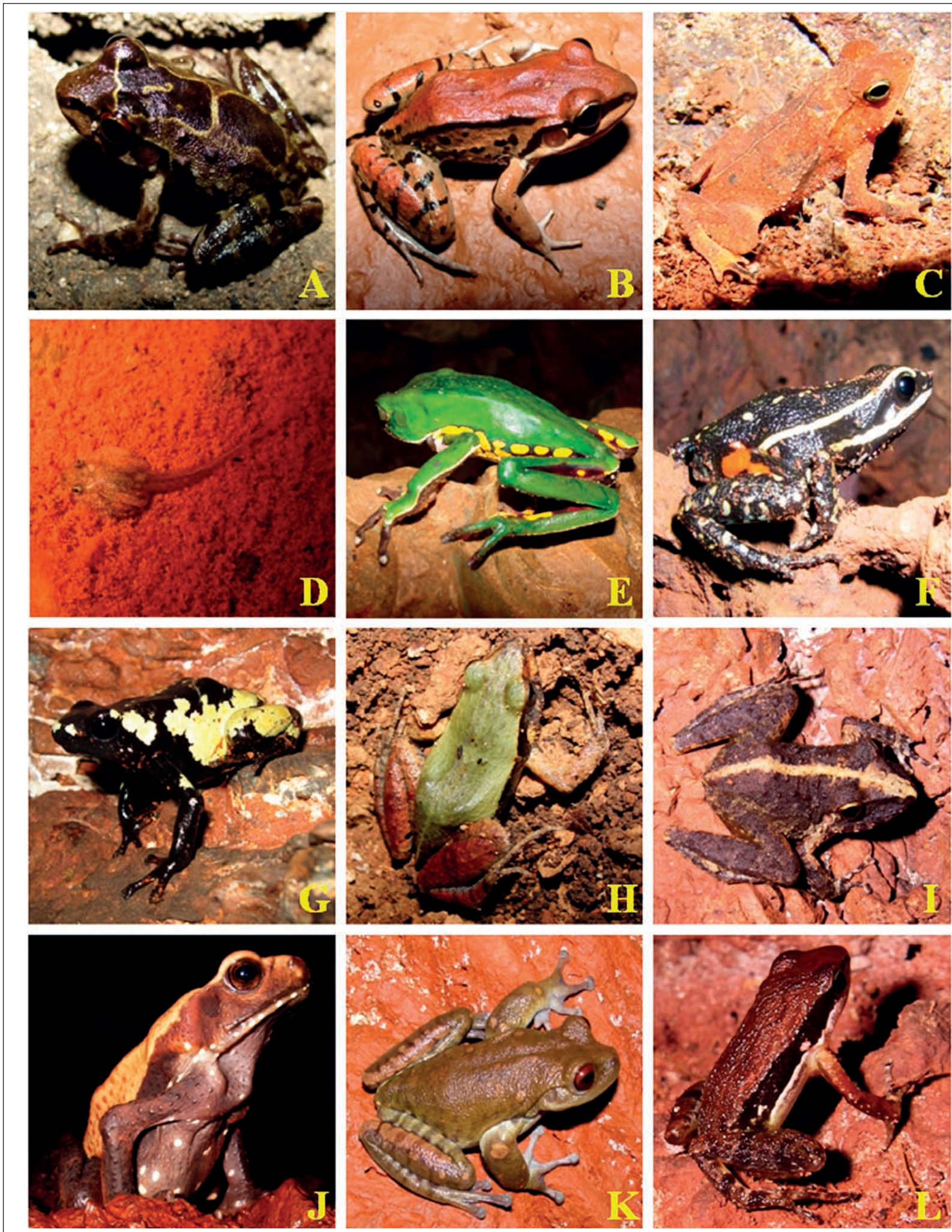

Fig. 2: Examples of some anuran species found in Brazilian caves of different biomes and lithologies: A) Thoropa taophora; B) Leptodactylus mystacinus; C) Rhinella aff. magnussoni; D) Tadpole sp.; E) Phyllomedusa aff. burmeisteri; F) Ameerega flavopicta; G) Adelphobates galactonotus; H) Physalaemus cuvieri; I) Pristimantis fenestratus; J) Rhaebo guttatus; K) Bokermannohyla martinsi and L) Allobates gr. marchesianus. 

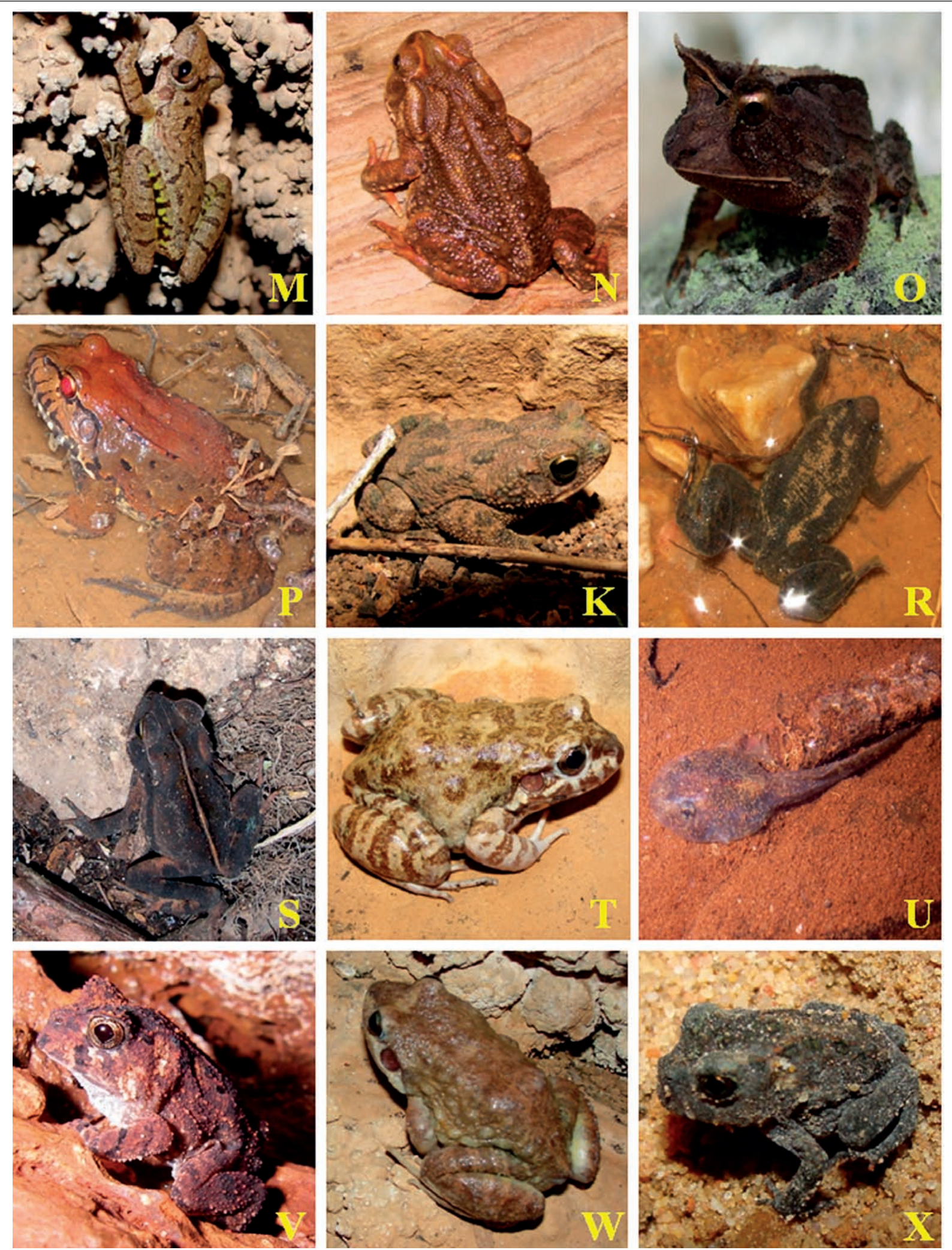

Fig. 3: M) Scinax fuscovarius; N) Rhinella rubescens; O) Proceratophrys boiei; P) Leptodactylus labyrinthicus; Q) Rhinella granulosa; R) Pipa carvalhoi; S) Rhinella crucifer; T) Leptodactylus troglodytes; U) Tadpole sp.1; V) Proceratophrys sp.; W) Leptodactylus syphax and $X)$ Rhinella sp. (juvenile). 


\section{DISCUSSION}

\section{RICHNESS OF ANURANS IN CAVE ENVIRONMENTS}

In recent decades the awareness and concern for biodiversity are increasing all over the world, especially in epigean environments. The same has occurred with the faunal studies in cave environments throughout the world (Culver \& Sket 2000; Vignoli et al. 2008; Del Castillo et al. 2009; Köhler 2010; Souza-Silva et al. 2011; Canedo et al. 2012; Ficetola et al. 2013). However, information about anurans in cave environments in Brazil is still scarce, particularly in the North and Northeast of the country (Souza-Silva \& Ferreira et al. 2009; Ferreira 2010). Furthermore, anurans found in Brazilian caves have been neglected for decades and the few existing citations show crude identifications (orders and families), the more refined identifications to the species level being rare (Pinto-da-Rocha 1995). On the other hand, in many countries, the occurrence of amphibians (salamanders and anurans) in subterranean systems is well documented (Lee 1969; Tyler \& Davies 1979; Bressi \& Dolce 1999; Prather \& Briggler 2001; Vignoli et al. 2008; Del Castillo et al. 2009; Köhler 2010; Manenti et al. 2011; Ficetola et al. 2013).

In the present study, the anurans associated with Brazilian caves proved to be very diverse in relation to work carried out in caves in Mexico and Northeastern Spain, where 27 and 9 species respectively, were found (Hoffmann et al. 1986; Galán 2002). This high richness of anuran species found in the caves of this study may be related to the high number of caves sampled in different biomes and lithologies. However, these comparisons are limited due to use of different methods in fauna surveys carried out in different studies.

In this study, the species of the Leiuperidae family showed the highest occurrence in cave environments and not the species of the Hylidae family, which have wide dominance in epigean environments (Duellman 1994), corroborating Gibert and Deharveng's (2002) hypothesis that the most diverse taxa in hypogean environments typically do not reflect the diversity of epigean environments. That is, some taxa are well represented below ground while others are rare or even absent. This inversion in the occurrence of families in epigean and hypogean environments may be related in part to the arboreal habits of most species of the family Hylidae.

Species of the family Hylidae make up $25 \%$ of the anurans in South America, being dominant throughout the Neotropics in open and forest formations, including different biomes in Brazil such as the Amazon, Atlantic Forest, Caatinga and Cerrado (Heyer et al. 1990; Arzabe 1999; Bertoluci \& Rodrigues 2002; Brasileiro et al. 2005;
Lima et al. 2006). However, most hylids have arboreal habits and successfully manage to occupy environments with extensive structural heterogeneity, such as forests, where they use vegetation as a vocalization platform (Cardoso et al. 1989; Bertoluci \& Rodrigues 2002). According Cardoso et al. (1989), the possession of digital expansion gives this group an advantage over terrestrial species. However, it is known that the aphotic condition of caves prevents the existence of vegetation in these environments and various studies have demonstrated that the absence of vegetation influences the anuran community, altering its abundance and even limiting their presence (Ernst \& Rödel 2005; Ernst et al. 2006). According to Martín et al. (2005), the absence of vegetation may increase the risk of predation of the arboreal anurans during vocalization activity, which may partly explain the low occurrence, or even the absence of species of the family Hylidae in most cave environments sampled, which may have favored the occurrence of families that have species with terrestrial habits.

The high occurrence of species of the family Leiuperidae in caves can be related to terrestrial habits, reproductive modes and the wide distribution of this family. In addition to the family Leiuperidae having terrestrial habits, which may have favored the occurrence in the cave environments sampled, this family is widely distributed in Central and South America (Grant et al. 2006). One example is the genus Physalaemus Fitzinger, 1826, which is a heterogeneous taxon encompassing 46 species grouped in seven groups: $P$. albifrons, $P$. cuvieri, P. deimaticus, $P$. gracilis, $P$. henselii, $P$. olfersii and P. signi$f e r$, the species of these groups being widely distributed in South America west of the Andes in open formations of Caatinga, Cerrado, Chaco and Llanos (Nascimento et al. 2005), corroborating our data, where the genus Physalaemus was also the most diverse in caves.

Another possible reason for the success of Leiuperidae family species in cave environments inserted in the biomes considered arid (Caatinga) and semiarid (Cerrado) is resistance to desiccation of eggs and larvae (Heyer 1969; Wilbur 1987; Moreira \& Lima 1991). According to Vasconcelos and Rossa-Feres (2005), this feature suggests that the species which have reproductive modes with deposition of eggs in foam nests (protection against desiccation) are favored in environments with unpredictable water level fluctuations, which may have led to a greater occurrence of the species in this family compared to the others, which do not have this feature. However, although most species of this family present reproductive modes adapted to arid and semiarid environments, low environmental 
heterogeneity caused by these landscapes, coupled with a pronounced dry season with unpredictability in the rainy season (Rossa-Feres \& Jim 2001), are additional factors that limit an variety of humid microhabitats needed by species with open area reproductive modes. Thus, these anuran species are perhaps seeking the cave environments simply because they provide more stable temperature and humidity than epigean environments (Trajano \& Bichuette 2006).

Due to the high dependence of anurans on high quality environments (high humidity and mild temperatures), the abiotic factors (rainfall, temperature and vegetation heterogeneity) have a higher effect on the anuran community structure than biotic factors such as competition and predation (Parris 2004; Werner et al. 2007). The above mentioned factors might also partly explain the search, by anurans, for cave environments, especially in arid and semiarid environments.

The high occurrence of the species S. fuscovarius (A. Lutz 1925) in caves may be related to its high plasticity (Cafofo-Silva et al. 2009). It is considered a generalist species in widely distributed in South America, being observed in Midwestern, Southeastern, Southern and Northeastern Brazil, occurring mostly in open areas of Cerrado biome, where it is usually found in high abundances, but is also observed in other environments like montane semi-deciduous seasonal forest, transition areas (Cerrado and semideciduous forest), pasture, plantations, anthropized areas and even inside residences (Brandão \& Araújo 2001; Ávila \& Ferreira 2004; Eterovick \& Sazima 2004; Brasileiro et al. 2005; Feio \& Ferreira 2005; Melo et al. 2007; Haddad et al. 1988). According to Duellman (1999), S. fuscovarius is found in open environments of the Cerrado-Caatinga-Chaco complex at altitudes ranging from 150 to $1800 \mathrm{~m}$.

The occurrence of S. fuscovarius in the caves can also be related to the climate of the arid and semiarid regions of the Caatinga and Cerrado biomes, where the majority of the specimens occurred. In these regions, the main problems for anurans in epigean environments are low humidity, high temperatures and rapid water loss through evaporation accompanied by a limited supply of water, which are considered limiting factors (Bentley 1966). According to Bentley (1966), the reproduction period of anurans in arid and semiarid regions coincides with the rainy season, when water is available, but if there is no or little rain, individuals cannot reproduce for several years. Therefore, cave environments inserted primarily in arid and semiarid regions, for presenting milder temperatures and higher relative humidity than the epigean environment, favor the colonization by anurans for protection, shelter, food and even reproduc- tion (Brown 1984; Trajano \& Bichuette 2006; Gouveia et al. 2009; Fellers et al. 2010). Thus, the simple selection of a microenvironment where conditions are more appropriate (caves) allows anurans to escape or mitigate the effects of climate (Bentley 1966; Arzabe 1999). This hypothesis corroborates Barr (1953), who, more than 50 years ago, suggested that anurans may seek caves to avoid the heat and dry conditions.

\section{BIOMES}

The colonization or invasion rates in cave environments may vary geographically (Christman et al. 2005), mainly in tropical regions, which present well defined seasonality and the occurrence and reproduction of most anuran species restricted to the rainy season (Rossa-Feres \& Jim 1994; Bertoluci \& Rodrigues 2002; Gottsberger \& Gruber 2004).

Our data showed a low occurrence of anurans in caves inserted in forested biomes (Amazon Forest and Atlantic Forest) which may be related to climate (high rainfall) and structural complexity of the vegetation of the epigean environments (Duellman 1999; Alencar et al. 2004; Bertoluci et al. 2007), which provide favorable environmental conditions for survival and reproduction of anuran species, which do not need to seek out caves as a refuge. In caves in the Amazon biome this was even more evident, because despite the large number of caves sampled, we verified a low occurrence of anurans in these caves. According to Duellman (1999), climate and vegetation type are generally considered the most important factors that determine the distribution of anuran species.

For the inserted caves in the arid (Caatinga) and semiarid (Cerrado) biomes and transition areas (Atlantic Forest and Cerrado), a considerable number of species were registered in comparison to the number of caves sampled. In the caves in the open biomes (Caatinga and Cerrado), anurans may be searching for subterranean environments to alleviate the risks of high temperatures and low humidity of the epigean environments, corroborating Del Castillo et al. (2009), in which the external environmental variables, such as temperature, solar radiation and relative humidity determined the organism distribution in caves in Mexico. These different strategies of anurans in seeking out caves as refuge to avoid low temperatures, hunger and for hibernation against the severe environmental conditions are already known in temperate areas (LópezOrtega \& Casas-Andreu 2005; Del Castillo et al. 2009). With respect to the caves inserted in transition areas (Atlantic Forest and Cerrado), this high species richness may be due to the presence of faunistic elements of both surrounding biomes. 


\section{LITHOLOGIES}

Caves are generally more abundant in karstic regions and volcanic areas (Cardoso 2012) and these differences in soil lithology properties influence the distribution of organisms (Souza-Silva et al. 2011).

The highest species richness of anurans found in Iron-ore caves in this study may simply be due to the greater number of caves sampled in this lithology, but Ferreira (2005) and Sousa-Silva et al. (2011), found a high relative richness of species for diverse taxa in Ironore cave environments. According to Ferreira (2005), the ferruginous subterranean systems have some peculiarities, such as a high faunal dissimilarity with other lithologies. In fact, our data also demonstrated this faunal uniqueness, where species of the Bokermannohyla group, Physalaemus aff. ephippifer and Rhinella marinus have only been recorded in Iron-ore caves.

Another important point regarding the occurrence of species in Iron-ore caves may be related to the genesis of these cavities. The caves in areas of Iron-ore are formed mainly in shallow gaps known as "canga" (Pilo and Auler 2005). Such systems have an extensive network of interstitial spaces (micro and meso caves) connected to the macro-caves, which significantly increases the availability and variety of habitats for maintaining a rich invertebrate fauna (Ferreira 2005), which may serve as food and favor the occurrence or even the permanence of some anuran species in these environments. These characteristics can possibly partially explain the richness of anuran species and the difference in species composition in relation to the other lithologies. Furthermore, we reiterated that in the ferruginous systems, the severity of the external environment is striking, which may also be leading to more anuran species taking shelter in these environments (Ferreira 2005).

On the other hand, the low richness found in marble, conglomerate, granite, quartzite and sandstone caves certainly reflects the low number of caves sampled in these lithologies, with the exception of the limestone caves, that in spite of the low number of caves sampled, presented a considerable number species.

\section{REPRODUCTION IN CAVE ENVIRONMENTS}

Some authors report that the cave environments are colonized accidentally (Wilkens 1979; Langecker 1989), leading to a widespread and misguided notion that all subterranean systems are inhospitable and resource-poor (Holsinger 2000; Romero \& Green 2005). The presence of tadpoles, juveniles belonging to the families Bufonidae (Rhinella sp.) and Hylidae (Dendropsophus aff. nanus) and the high occurrence of adult anurans in this study, demonstrate otherwise and confirms other surveys conducted in caves where the presence of tadpoles, juveniles and adults was found (Brown 1984; Trajano 1987; Trajano \& Gnaspini-Netto 1991; Trajano \& Bichuette 2006; Ferreira et al. 2009; Köhler et al. 2010; Canedo et al. 2012; Ficetola et al. 2013), which reinforces the hypothesis that some caves are not inhospitable environments with scarce resources; they may serve as shelter, protection, harbor food sources and, even as breeding sites for some anuran species (Brown 1984; Trajano \& Bichuette 2006; Fellers et al. 2010).

\section{CONSERVATION OF CAVE ENVIRONMENTS}

Biomes such as the Amazon, Atlantic Forest, Caatinga and Cerrado come under heavy anthropogenic pressure, especially by the transformation of native vegetation into pastures, agricultural land, logging activities and construction of cities (Myers et al. 2000; Alencar et al. 2004; Leal et al. 2005; Klink \& Machado 2005). However, the caves inserted in these biomes are also susceptible to the same threats as the epigean environments, because the hypogean cave environments are extremely vulnerable to anthropic activities, which generate different impacts on subterranean ecosystems (Van Beynen \& Townsend 2005; Calo \& Parise 2006; Ford 2007). These anthropic factors, particularly deforestation, cause generalized depletion (species richness) of anuran communities, in which a low number of species adapted to open condi- tions replaces the great diversity of species specialized to forest environments (Haddad \& Prado 2005).

Among the major threats to subterranean ecosystems, the removal of vegetation in the epigean environment is perhaps the main impact on the biological communities present in these ecosystems. On the other hand, with the destruction and loss of natural epigean habitats, the caves, because they have a stable environment regarding humidity and temperature, become places of refuge conducive to rest, feeding and even reproduction for some anuran species (Trajano \& Bichuette 2006; Gouveia et al. 2009; Fellers et al. 2010). However, since 2008, caves are at serious risk, because with the new decree, all Brazilian caves that were fully protected by law, can now be destroyed by different anthropic activities. 


\section{CONCLUSIONS}

The great diversity of anurans found in Brazilian caves, plus the decline of these populations, sound an alert to the importance of taxonomic inventories in both the epigean (biomes) and hypogean (caves) environments, aiming at the preservation of caves as shelter for a wide diversity of taxa.

\section{ACKNOWLEDGEMENTS}

To all from the Laboratório de Ecologia Subterrânea (UFLA) for their help in the field works. The authors thank Gustavo Klinke for editing the map works. R. L. Ferreira is grateful to the National Council of Techno- logical and Scientific Development (CNPq) (process No. 301061/2011-4) for the research grant and to FAPEMIG for the financial support.

\section{REFEFENCES}

Alencar, A., Nepstad, D., McGrath, D., Moutinho, P., Pacheco, P., Diaz, M., Del, C.V. \& B. Soares Filho, 2004: Desmatamento na Amazônia: indo além da "emergência crônica".- Instituto de Pesquisa Ambiental da Amazônia, pp. 85, Belém.

Ávila, R.W. \& V.L. Ferreira, 2004: Riqueza e densidade de vocalizações de anuros (Amphibia) em uma área urbana de Corumbá, Mato Grosso do Sul, Brasil.Revista Brasileira de Zoologia, 4, 21, 887-892.

Arzabe, C., 1999: Reproductive activity patterns of anurans in two different altitudinal sites within the Brazilian Caatinga.- Revista Brasileira de Zoologia, $16,3,851-864$.

Auler, A., Brandi, R. \& E. Rubiolli, 2001: As Grandes Cavernas do Brasil.- Orion, pp. 227, Belo HorizonteMG.

Barr Jr., T.C., 1953: Notes on the occurrence of ranid frogs in caves.- Copeia, 1953, 1, 60-61.

Bentley, P.J., 1966: Adaptations of Amphibia to arid environments.- Science, 152, 3722, 619-623.

Bertoluci, J. \& M.T. Rodrigues, 2002: Utilização de habitats reprodutivos e micro-habitats de vocalização em uma taxocenose de anuros (Amphibia) da Mata Atlântica do sudeste do Brasil.- Papéis Avulsos de Zoologia, São Paulo, 42, 11, 287-297.

Bertoluci, J., Brassaloti, R.A., Ribeiro Jr., J.W., Vilela, V.M.F.N. \& H.O. Sawakuchi, 2007: Species composition and similarities among anuran assemblages of forest sites in southeastern Brazil.- Scientia Agricola, 64, 4, 364-374.
Brandão, R.A. \& A.F.B. Araujo, 2001: A Herpetofauna da Estação Ecológica de Águas Emendadas.- In: Marinho, F.J. et al. (eds.) Vertebrados da Estação Ecológica de Águas Emendadas, História Natural e Ecologia em um fragmento de cerrado do Brasil Central, Brasília, DF. SEMATEC/IEMA, pp. 560-604, Brasília.

Brasileiro, C.A., Sawaya, R.J., Kiefer, M.C. \& M. Martins, 2005: Amphibians of an open Cerrado fragment in southeastern Brazil.- Biota Neotropica, 5, 2, 1-17.

Bressi, N. \& S. Dolce, 1999: Osservazioni di Anfibi e Rettili in grotto.- Rivista di Idrobiologia, 38, 475-481.

Brown Jr., D.R., 1984: Rana palustris - oviposition.- Herpetological review, 15, 15-110.

Cafofo-Silva, E.G., Delariva, R.L. \& I.P. Affonso, 2009: Distribuição espaço-temporal de Scinax fuscovarius (lutz, 1925) (anura, hylidae) em Maringá - PR, Brasil.- Revista em Agronegócios e Meio Ambiente, 2, 3, 431-445.

Calo, F. \& M. Parise, 2006: Evaluating the human disturbance to karst environments in southern Italy.- Acta Carsologica, 35, 2, 47-56.

Canedo, C., Targino M., Leite, F.S.F. \& C.F.B Haddad, 2012: A new species of Ischnocnema (Anura) from the São Francisco basin karst region, Brazil.- Herpetologica, 68, 3, 393-400.

Cardoso, A.J., Andrade, G.V. \& C.F.B Haddad, 1989: Distribuição espacial em comunidades de anfíbios (Anura) no sudeste do Brasil.- Revista Brasileira de Biologia, 49, 1, 241-249.

Cardoso, P., 2012: Diversity and community assembly patterns of epigean vs. troglobiont spiders in the Iberian Peninsula.- International Journal of Speleology, 41, 83-94. 
Christman, M.C., Culver, D.C., Madden, M.K. \& D. White, 2005: Patterns of endemism of the eastern North American cave fauna.- Journal of Biogeography, 32, 1441-1452.

Collins, J.P. \& A. Stofer, 2003: Global amphibiam declines: sorting the hypotheses.- Diversity and Distributions, South Africa, 9, 2, 89-98.

Culver D.C. \& B. Sket, 2000: Hotspots of subterranean biodiversity in caves and wells.- Journal of Cave and Karst Studies, 62, 11-17.

Culver, D., Christman, M., Sket, B. \& P. Trontelj, 2004: Sampling adequacy in an extreme environment: species richness patterns in Slovenian caves.- Biodiversity and Conservation, 13, 6, 1209-1229.

Del Castillo, A. E., Castanõ-Meneses, G., Dávila-Montes, M.J., Miranda-Anaya, M., Morales-Malacara, J.B. \& R. Paredes-León, 2009: Seasonal distribution and circadian activity in the troglophile long-footed robber frog, Eleutherodactylus longipes (Anura: Brachycephalidae) at los riscos cave, Querétaro, México, Field and Laboratory studies.- Journal of Cave and Karst Studies, 71, 24-31.

Duellman, W.E. \& L. Trueb, 1994: Biology of Amphibians.- The Johns Hopkins University Press, pp. 670, Baltimore.

Duellman, W.E., 1999: Distribution patterns of amphibians in South America.- In: Duellman, W.E. (eds.) Patterns of Distribution of Amphibians: A Global Perspective. Johns Hopkins University Press, pp. 255-328, Baltimore.

Elliott, W., 2000: Conservation of the North American cave and karst biota.- In: Wilkens, H. et al. (eds.) Subterranean ecosystems: Ecosystems of the World. Elsevier, pp. 665-669, Amsterdam.

Ernst, R. \& M.O. Rodel, 2005: Anthropogenically induced changes of predictability in tropical anuran assemblages.- Ecology, 86, 11, 3111-3118.

Ernst, R., Linsenmair, K.E. \& M.O. Rödel, 2006: Diversity erosion beyond the species level: dramatic loss of functional diversity after selective logging in two tropical amphibian communities.- Biological Conservation, 133, 2, 143-155.

Eterovick, P.C. \& I. Sazima, 2004: Anfíbios da Serra do Cipó, Minas Gerais, Brasil.-Editora PUC Minas, pp. 152, Belo Horizonte.

Feio, R.N. \& P.L. Ferreira, 2005: Anfíbios de dois fragmentos de Mata Atlântica na Zona da Mata de Minas Gerais.- Revista Brasileira de Zoociências, 7, 1, 121-128.

Fellers, G.M., Wood, L.L., Carlisle, S. \& D. Pratt, 2010: Unusual subterranean aggregations of the California giant salamander, Dicamptodon ensatus.- Herpetological Conservation and Biology, 5, 1, 149-154.
Ferreira, R.L., 2005: A vida subterrânea nos campos ferruginosos.- O Carste, 3, 17, 106-115.

Ferreira, R.L., Bernardi, L.F.O. \& M.S Silva, 2009: Caracterização dos ecossistemas das grutas Aroê Jarí, Kiogo brado e lago azul (Chapada dos Guimarães, MT): Subsídios para o turismo nestas cavidades.Revista de Biologia e Ciências da Terra, 9, 1, 41-58.

Ferreira, R.L., Prous, X., Bernardi, L.F.O. \& M. SouzaSilva, 2010: Fauna subterrânea do estado do Río Grande do Norte: Caracterização e impactos.- Revista Brasileira de Espeleologia, 1, 1, 25-51.

Ficetola, G.F., Pennati, R. \& R. Manenti, 2013: Spatial segregation among age classes in cave salamanders: habitat selection or social interactions?.- Population Ecology, 55, 1, 217-226.

Ford, D.C. \& P.W. Williams, 2007: Karst hydrogeology and geomorphology, British Library Cataloguing in Publication Data.- Blackwell Publishers, pp. 601, Oxford.

Galán, P., 2002: Galicia.- In: Pleguezuelos, J.M. et al. (eds.) Atlas y libro rojo de los Anfibios y Reptiles de España. Dirección General de Conservación de la Naturaleza. Asociación Herpetologica Española, pp. 467, Madrid.

Gibert, J. \& L. Deharveng, 2002: Subterranean ecosystems: a truncated functional biodiversity.- Bioscience, 52, 6, 473-481.

Grant, T., Frost, D.R., Caldwell, J.P., Gagliardo, R., Haddad, C.F.B., Kok, P.J.R., Means, D.B., Noonan, B.P., Schargel, W.E. \& W.C. Wheeler, 2006: Phylogeneyic systematics of Dart-Poison Frogs and their relatives (Amphibia: Athesphatanura: Dendrobatidae).- Bulletin American Museum of Natural History, 1, 299, $1-262$.

Godoy, N.M., 1986: Nota sobre a fauna cavernícola de Bonito, Mato Grosso do Sul.- Espeleo-Tema, 15, 79-91.

Gottsberger, B. \& E. Gruber, 2004: Temporal partitioning of reproductive activity in a Neotropical anuran community.- Journal of Tropical Ecology, 20, 3, 271-280.

Gouveia, S.F., Rocha, P.A., Mikalauskas, J.S. \& V.V. Silveira, 2009: Rhinella Jimi (Cururu Toad) and Leptodactylus Vastus (Northeastern Pepper Frog). Predation on bats.- Herpetological Review, 40, 2, 1.

Haddad, C.F.B., Andrade, G.V. \& A.J. Cardoso, 1988: Anfíbios anuros no Parque Nacional da Serra da Canastra, Estado de Minas Gerais.- Brasil Florestal, 64, 24, 9-20.

Haddad, C.F.B. \& C.P.A. Prado, 2005: Reproductive Modes in Frogs and Their Unexpected Diversity in the Atlantic Forest of Brazil.- BioScience, 55, 3, 207-217. 
Heyer, W.R., 1969: The adaptive ecology of the species groups of the genus Leptodactylus (Amphibia, Leptodactylidae).- Evolution, 23, 4, 421-428.

Heyer, W.R., Rand, A.S., Da Cruz, C.A.G., Peixoto, O.L. \& C.E. Nelson, 1990: Frogs of Boracéia.- Arquivos de Zoologia, 34, 4, 231-410.

Heyer, W.R, Donnelly, M.A., McDiarmid, R.W., Hayek, L.C. \& M.S. Foster, 1994: Measuring and monitoring biological diversity: standard methods for amphibians.- Smithsonian Institution Press, pp. 364, Washington.

Hoffmann, A., Palacios-Vargas, J.G. \& J.B. Morales-Malacara, 1986: Manual de bioespeleología (con nuevas aportaciones de Morelos y Guerrero, México).- Universidad Nacional Autónoma de México, pp.274, México.

Holsinger, J.R. \& D.C. Culver, 1988: The invertebrate cave fauna of Virginia and a part of eastern Tennessee: Zoogeography and ecology.- Brimleyana, 14, $1-162$.

Holsinger, J.R., 2000: Ecological derivation, colonization, and speciation.- In: Wilkens, H. et al. (eds.) Subterranean Ecosystems. Elsevier, pp. 399-415, Amsterdam.

Klink, C.A. \& R.B. Machado, 2005: A conservação do Cerrado brasileiro.- Megadiversidade, 1, 1, 147-155.

Köhler, J., Vences, M., D’Cruze, N. \& F. Glaw, 2010: Giant dwarfs: discovery of a radiation of large-bodied 'stump-toed frogs' from karstic cave environments of northern Madagascar.- Journal of Zoology, 282, 21-38.

Krajick, K., 2001: Cave biologists unearth buried treasures.- Science, 283, 2378-2381.

Langecker, T.G., 1989: Studies on the light reaction of epigean and cave populations of Astyanax fasciatus (Characidae, Pisces).- Memoires de Biospeólogie, $16,169-176$.

Leal, I.R., da Silva, J.M.C., Tabarelli, M. \& T.E. Lacher Jr., 2005: Mudando o curso da conservação da biodiversidade na Caatinga do Nordeste do Brasil.- Megadiversidade, 1, 1, 139-146.

Lee, D.S., 1969: Notes on the Feeding Behavior of CaveDwelling Bullfrogs Source.- Herpetologica, 25, 3, 211-212.

Lima, A.P., Magnusson, W.E., Menin, M., Erdtmann, L.K., Rodrigues, D.J., Keller, C. \& W. Hodl, 2006: Guia de sapos da Reserva Adolpho Ducke, Amazônia Central.- Áttema Design Editorial, pp. 168, Manaus.
López-Ortega, G. \& G. Casas-Andreu, 2005: A tunnel as hibernaculum of Hyla plicata (Anura: Hylidae) at Sierra Norte de Tlaxco, Tlaxcala, México.- Revista de la Sociedad Mexicana de Historia Natural, 2, 1, 160-167.

Manenti, R, Ficetola, G.F., Marieni, A. \& F. De Bernardi, 2011: Caves as breeding sites for Salamandra salamandra: habitat selection, larval development and conservation issues, North-West..- Journal of Zoology, 7, 304-309.

Martín J, Luque-Larena, J.J. \& P. López, 2005: Factors affecting scape behavior of Iberian green frogs (Rana perezi).- Canadian Journal of Zoology, 83, 9, 1189-1194.

Melo, G.V., Rossa-Feres, D.C. \& J. Jim, 2007: Variação Temporal no sítio de vocalização em uma comunidade de anuros de Botucatu, Estado de São Paulo, Brasil.- Biota neotropica, 7, 2, 93-102.

Myers, N., Mittermeier, R.A., Mittermeier, C.G., Fonseca, G.A.B. \& J. Kent, 2000; Biodiversity hotspots for conservation priorities.- Nature, 403, 6772, 853-845.

Moreira, G. \& A.P. Lima, 1991: Seasonal patterns of juvenile recruitment and reproduction in four species of leaf litter frogs in central Amazonia.- Herpetologica, 47, 3, 295-300.

Nascimento, L.B., Caramaschi, U. \& C.A.G. Cruz, 2005: Taxonomic review of the species groups of the genus Physalaemus fitzinger, 1826 with revalidation of the genera Engystomops jiménez-de-la-espada, 1872 and Eupemphix steindachner, 1863 (Amphibia, Anura, Leptodactylidae).- Arquivos do Museu Nacional, Río de Janeiro, 63, 2, 297-320.

Parris, K.M., 2004: Environmental and spatial variables influence the composition of frog assemblages in sub-tropical eastern Australia.- Ecography 27, 3, 92-400.

Piló, L.B. \& A.S. Auler, 2005: Cavernas em minério de ferro e canga de Capão Xavier, Quadrilátero ferrífero, Minas Gerais.- O Carste, 3, 17, 92-105.

Pinto-da-Rocha, R., 1995: Sinopse da fauna cavernícola do Brasil (1907-1994).- Papéis Avulsos de Zoologia, $39,6,61-173$.

Prather, J.W. \& J.T. Briggler, 2001: Use of small caves by anurans during a drought period in the Arkansas Ozarks. Journal of Herpetology, 35, 675-678.

Romero, A. \& S.M. Green, 2005: The end of regressive evolution: examining and interpreting the evidence from cave fishes.- Journal of Fish Biology, 67, 3-32.

Rossa-Feres, D.C. \& J. Jim, 1994: Distribuição sazonal em comunidades de anfíbios anuros na região de Botucatu, São Paulo.- Revista Brasileira de Biologia, Botucatu, 54, 2, 323-334. 
Rossa-Feres, D.C. \& J. Jim, 2001: Similaridade do sítio de vocalização em uma comunidade de anfíbios anuros na região noroeste do Estado de São Paulo, Brasil.- Revista Brasileira de Biologia, 18, 2, 439-454.

Segalla, M.V., U. Caramaschi, C.A.G. Cruz, P.C.A. Garcia, T. Grant, C.F.B. Haddad, and J. Langone, 2014. Brazilian amphibians - List of species. Accessible at http://www.sbherpetologia.org.br. Sociedade Brasileira de Herpetologia. Captured on 05 July 2015.

Souza-Silva, M. \& R.L. Ferreira, 2009: Caracterização ecológica de algumas cavernas do Parque Nacional de Ubajara (Ceará) com considerações sobre o turismo nestas cavidades.- Revista de Biologia e Ciências da Terra, 1, 9, 59-71.

Souza-Silva, M., Martins, R.P. \& R.L. Ferreira, 2011: Cave lithology determining the structure of the invertebrate communities in the Brazilian Atlantic Rain Forest.- Biodiversity and Conservation, 8, 20, 1713-1729.

Trajano, E. 1987: Fauna cavernicola brasileira: Composição e caracterização preliminar.- Revista brasileira de Zoologia, São Paulo, 3, 8, 533-561.

Trajano, E. \& P. Gnaspini-Netto, 1991: Composição da fauna cavernícola brasileira, com uma analise preliminar da distribuição dos táxons.- Revista brasileira de Zoologia, 7, 3, 383-407.

Trajano, E. \& J.R.A. Moreira, 1991: Estudo da fauna de cavernas da província espeleológica arenítica Altamira-Itaituba, Pará.- Revista Brasileira de Biologia, $51,1,13-29$.

Trajano, E. \& M.E. Bichuette, 2006: Biologia Subterrânea: Introdução.- Redespeleo, pp. 92, São Paulo.

Tyler, M.J. \& M. Davies, 1979: A new species of cavedwelling, hylid frog from mitchell plateau, western Australia.- Transactions Royal Society of South Australia, 103, 6, 149-153.
Van Beynen, P. \& K. Townsend, 2005: A disturbance index for karst environments.- Environ Manage, 36, $1,101-116$.

Vasconcelos, T.S. \& D.C. Rossa-Feres, 2005: Diversidade, distribuição espacial e temporal de anfíbios anuros (Amphibia, anura) na região noroeste do Estado de São Paulo, Brasil.- Biota Neotropica, 5, 2, 1-14.

Vignoli, L., Caldera, F. \& M.A. Bologna, 2008: Spatial niche of the Italian cave salamander, Speleomantes italicus (Dunn, 1923) (Plethodontidae, Amphibia), in a subterranean system of Central Italy.- Italian Journal of Zoology, 75, 59-65.

Zeppelini, D., Ribeiro, A.C., Ribeiro, G.C., Fracasso, M.P. A., Pavani, M.M., Oliveira, O.M.P., Oliveira, S.A. \& A.C. Marques, 2003: Faunistic survey of the sandstone caves from Altinópolis region, São Paulo State, Brazil.- Papéis Avulsos de Zoologia, São Paulo, Brasil, 43, 5, 93-99.

Werner, E.E., Yurewicz, K.L., Skelly, D.K. \& R.A. Relyea, 2007: Turnover in an amphibian metacommunity: the role of local and regional factors.- Oikos, 116, 10, 1713-1725.

Wilbur, H.M., 1987: Regulation of structure in complex systems: experimental temporary pond communities.- Ecology, 68, 5, 1437-1452.

Wilkens, H., 1979: Reduktionsgrad und phylogenetisches alter: ein beitrag besiedlungsgeschichte der limnofauna Yukatans.- Zeitschrift fur Zoologische Systematik und Evolutionsforschung, 17, 262-272.

Wynne, J.J. \& W. Pleytez, 2005: Sensitive ecological areas and species inventory of Actun Chapat Cave, Vaca Plateau, Belize.- Journal of Cave and Karst Studies, 67, 148-157. 